\title{
Spurring entrepreneurial intensity through social capital and relationship quality
}

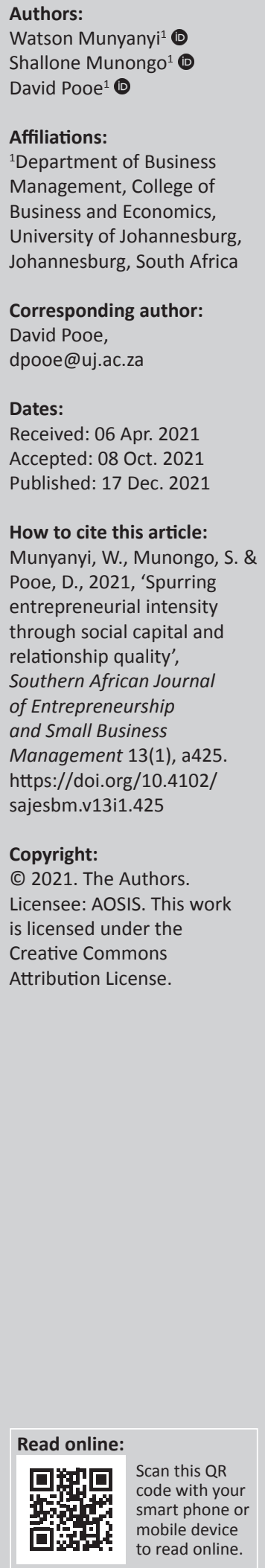

Background: The rapid increase in the pace of globalisation has been met with increased calls for sustainability as a means to entrepreneurship development. As entrepreneurship and sustainability continue to gain recognition, entrepreneurial intensity has emerged as a critical component of the ecosystem. The entrepreneurial intensity notion conceptualised the extent and frequency of innovation, risk taking, and proactiveness within an organisation.

Aim: This study investigated how social interaction and relationship quality, referred to as social capabilities, influences entrepreneurial intensity.

Setting: The population comprised all small and medium enterprises (SMEs) in Zimbabwe. An online questionnaire constructed using Google Docs was posted on Masvingo centred Facebook and WhatsApp groups from 15 October 2018 to 19 December 2018.

Methods: Based on an extensive review of the theoretical and empirical literature, hypotheses were formulated and then tested using the structural equation modelling framework. The study was based on a sample of 312 SMEs selected through convenience sampling, and data were collected through a self-administered questionnaire based on a five-point Likert scale.

Results: The study results back the propositions that social interaction and relationship quality are strongly and positively related to entrepreneurial intensity.

Conclusion: In light of the findings, several recommendations are made, but generally, to promote superior innovativeness, risk taking and proactiveness, firms must concentrate on steering up and refining their social capabilities.

Keywords: social interaction; relationship quality; entrepreneurial intensity; social capabilities formation; sociability; social presence; online social interactions; SMEs.

\section{Introduction}

Notwithstanding the avalanche of diversity that characterises its definition, entrepreneurship has long been viewed as a global tool for stimulating economic growth and a pointer of economic vigour (Adusei 2016; Kamakula \& Patro 2019). In most sub-Saharan countries, the population has grown faster than employment growth, obliging the emergence of productive entrepreneurship to deal with unemployment and poverty (Napitupulu et al. 2018; Niebel 2018; Zafar \& Mustafa 2017). Consequently, there has been a general shift in policy, emerging from this growth in the insight that entrepreneurship and small and medium enterprises (SMEs) are proxies for successful economic growth and development (Dimova \& Pela 2018; Dzisi, Odoom \& Gligah 2018). Governments and policymakers actively support entrepreneurial ventures' creation and growth through financial incentives, business incubators, relaxation of administrative barriers and educational programmes (Auzoult, Lheureux \& Abdellaoui 2016). In Zimbabwe, although somehow ambivalent towards informal entrepreneurship, government policy has supported the growth of small businesses (Mujeyi \& Sadomba 2019; Nyoni \& Bonga 2018). However, despite these efforts, entrepreneurial activity has remained generally low, especially in developing countries (Eijdenberg et al. 2018; Fischer, Queiroz \& Vonortas 2018), signalling that different approaches are still needed to enhance entrepreneurship. New strategies and setups are being explored to assist SMEs and entrepreneurs in developing business ideas and growing (Stephens, Partridge \& Faggian 2013).

There is also an extensive acceptance that extraordinary performance and growth amongst SMEs depends heavily on the entrepreneur's capabilities (Mitchelmore \& Rowley 2013). According to Boada-Grau et al. 2016), governments must not only focus on providing small businesses with resources such as capital and easy financing but should also strive to assess their socio-psychological skills, motivations and experiences. In developing economies like Zimbabwe, SMEs have proved to be the panacea to economic challenges. Hence, to ensure sustainable economic transformation, superior 
entrepreneurial intensity (EI) levels are indispensable (Siddiqui \& Jan 2017). Building on the social exchange theory (SET), scholars believe that inter-organisational capital, obtainable through social and other capabilities formation has the potential to influence EI amongst firms and entrepreneurs and consequently an enduring competitive advantage (Cao, Duan \& Cadden 2019; Huo et al. 2019). Social networking is progressively becoming more imperative to entrepreneurs because of its ability to help firms recognise valuable opportunities (Shu, Ren \& Zheng 2018). Social capabilities generally refer to particular skills that enable entrepreneurs to use their interpersonal skills to achieve economic benefits. In today's commercial environment, it has become essential that entrepreneurs develop and exploit valuable dynamic managerial capabilities (Huy \& Zott 2019), and modern businesses continuously revamp, reorganise and reconstruct their competencies in order to deal with extreme competition and ensure safe market positioning (Wang 2016). However, despite the theoretical and empirical significance of social capabilities, there is an odd absence of conclusive research on the critical influence of entrepreneurship research's social capabilities.

Although individually the levels may vary, entrepreneurs generally require a high-intensity level to drive them towards business success. Therefore, this study seeks to investigate the influence of social capabilities on EI, integrating two significantbut disconnected research streams. Entrepreneurial intensity has generally been studied at the firm level (Morris, Kuratko \& Covin 2010; Scheepers, Hough \& Bloom 2007), and there is a great need for this construct to be studied at an individual level in order to empirically assess the altitude and rate of recurrence of entrepreneurship amongst entrepreneurs. Although there has been substantial progress so far in clearing the social capital notion, knowledge of how social capital affects EI remains unclear. In fact, there is a limited understanding of the dimensions of social capital that entrepreneurs should focus on. More scholarly, work is required on the role social capital play in fostering EI, particularly in developing economies contexts, as it remains poorly explored. In addition, the surge in social media platforms has revived scholarly interest in social capital as these platforms afford new ways to interact and build relationships. Drawing from the SET, the article develops an EI model relevant to the developing country context in the general and Zimbabwean context. Since 2000, Zimbabwe's economy has been underperforming, spurring the cost of living and unemployment rates (Mazhambe 2017). This study outlines the dimensions of social capabilities that entrepreneurs should develop to foster their EI.

\section{Literature review}

\section{Informal sector and entrepreneurship in Zimbabwe}

In most developing economies, the informal sector is growing remarkably, claiming a significant share of economic activity. Likewise, in Zimbabwe, the sector accounts for an estimated
$60.6 \%$ of the total gross domestic product (GDP) and $90 \%$ of the national labour force (Medina \& Schneider 2018). Although most of the businesses are largely unregistered and some operating in illegal premises, there is significant evidence of entrepreneurship and innovation flourishing in the informal sector of Zimbabwe. According to Muzurura (2019), Zimbabwe's entrepreneurial ecosystem remains very fertile, owing to the high literacy levels in the country and the high levels of resilience and ability to identify opportunities, incubate new startups and take up calculated risks. The government has responded by embracing informality and making it a policy priority and top of the inclusive growth and sustainability agenda (Mujeyi \& Sadomba 2019). Although commendable efforts have been made by the government in this regard, cumbersome bureaucracy, stringent regulations and corruption rentals have slowed down the pace of entrepreneurship growth in Zimbabwe. Muzurura (2019) states that corruption is amongst the impediments to entrepreneurship in Zimbabwe, which tends to have a sanding instead of greasing 'effect on the wheels of entrepreneurship growth'.

\section{Social capital}

Social capital, defined as a set of socio-structural resources derived from social relationships that enable individuals, groups or teams, coordinates action to desired outcomes (Carrillo Álvarez \& Riera Romaní 2017) has increased in understanding social and business relations. According to Suseno (2018), the underlying idea behind social capital is that actors' relationships and ties with others matter, as they help provide resources or benefits to create value and positive outcomes for the organisation. Social capital has helped explain firm growth, success and resilience, sparking overwhelming interest amongst practitioners and scholars. In this sense, social interaction, social presence and relationship quality will positively impact an organisation's wealth by reducing transaction costs and enabling collective actions (Andriani \& Christoforou 2016). Building on the work of Kreijns and Kirschner (2002), social capital can be measured in terms of sociability and social presence of the entrepreneur and their level of online social interaction.

\section{Sociability}

According to Kreijns et al. (2007), sociability relates to the extent to which an individual or an environment facilitates the emergence of a sound social space characterised by trust, a strong sense of belonging and good working relationships. Henriksson (2019) expands on the above definition by stating that sociability relates to the informal interaction between individuals without the influence of any subject matter external to the current situation. It is the kind of interaction that foregoes the creation of a group to maintain the situation open to all forms of interaction. In this context, sociability can be said to relate primarily to fitting in and adapting oneself to the situation and foregoing one's personal motivations for being present (Henriksson 2019). Evidently, the type and superiority of connections between stakeholders will 
influence the business's nature and quality performance outcomes (McLeod \& MacDonell 2011). Sociability is thus a critical element in enhancing relationship building and collaboration amongst entrepreneurs. In the current world of the COVID-19 pandemic, sociability has been identified as a critical factor in shaping disease susceptibility and how fast actors respond to its spread (Borgonovi \& Andrieu 2020). The development of new technologies has presented entrepreneurs and firms with a greater opportunity to create emotional connections with stakeholders and safeguard consumer loyalty (Olavarría-Jaraba et al. 2018).

\section{Social presence}

Social presence has been described as the feeling of being socially present even though one is not physically in a particular space (Kim, Song \& Luo 2016). The operationalisations of social presence have been expanded to include social interaction, immediacy, intimacy, emotion and connectedness. Scholars like Short, Williams and Christie (1976:65) have conceptualised social presence as the 'degree of salience of the other person in the interaction and the consequent salience of the interpersonal relationships'. Thus, the degree of social presence relates to the subjective experience of presence by the natural person, both in terms of thoughts and emotions (Lowenthal \& Snelson 2017). The capacity to identify social interactions is embedded in humans and is manifested in the primary stages of development, affecting both cognition and behaviour (Choi \& Luo 2015; Hamlin et al. 2011; Tatone, Geraci \& Csibra 2015). There is a growing consensus that social interactions play a vital role in influencing human behaviour (Crawford \& Harris 2018). The informal connection amongst individuals plays a significant role in promoting engagement and social presence. It is believed that significant social interactions transversely across a cognitive space are made possible by the existence of trust (Hoffmann \& Söllner 2014; Ojansivu \& Alajoutsijärvi 2015; Park \& Lee 2014), which enables the parties to make a clear understanding of each other's perceptions (Grabher \& Ibert 2014; Mueller 2015). Furthermore, McLeod and MacDonell (2011) argue that the prerequisite to understanding the explanatory organisational and individual parameters like social interactions management may not be overemphasised.

\section{Online social interactions}

In recent years, online social media interaction, through social networking sites (SNSs), has evolved to become an integral part of people's daily lives worldwide, altering the way people communicate and socially interact (Moretta \& Buodo 2018). The general increase and expansion in information and communication technologies have significantly improved the way individuals and businesses interact, team up and network (De Choudhury et al. 2010). These SNSs facilitate the culmination and continuance of social interactions online, and they have become entrenched ways in which people communicate today (Khalis \& Mikami 2018). Firms have also started using social media platforms like Facebook and Twitter to smoothen the advancement towards social interaction amongst customers and employees beyond the context of corporate emails and memos (Burrus 2010). Social interaction refers to the process of behaving and conversing with one another, predominantly in an informal way (Choi \& Kim 2004). Firms that can organise resources such as information and social influence potentially benefit these resources depending on the firm's ability to mobilise these resources in its favour (Herrero 2015).

\section{Relationship quality}

Relationship quality relates to the strength of a relationship between parties, including the satisfaction, trust, assurance and social benefit between the parties involved (Japutra, Molinillo \& Wang 2018). Relationship quality has been theorised as a higher-order construct consisting of several distinct dimensions, including trust and satisfaction, which are considered an 'emotional state that occurs in response to an evaluation of these interaction experiences' (Huntley 2006; Liu, Guo \& Lee 2011; Su, Swanson, \& Chen 2016). Relationship quality is considered a factor in developing loyal consumers, employees and suppliers (Walsh et al. 2010; Lo et al. 2018) and tourists' environment-related conduct (He et al. 2018). Empirical studies show that relationship quality is valuable in predicting customer behaviour (Hyun 2010; Jin et al. 2013) and is central to organisational decision-making (Morgan \& Hunt 1994). Other scholars have indicated that relational quality is developed by enhancing stakeholder experience (Hyun 2010). Whilst the central view is that business relationships are determined by legislative limits and measures such as partnerships and alliances, hands-on management of relationships is of tactical and strategic importance (Jelodar, Yiu \& Wilkinson 2016). In addition, as stated by Feeney and Fitzgerald (2018), lack of emotional attachment, insecurity and connected conflict behaviours wear down relationship quality. Therefore, at the core of relationship quality is recognising and fulfilling the needs of parties in a relationship, and relationship quality theory suggests that satisfied stakeholders reward with continuing value over time (He et al. 2018).

\section{Entrepreneurial intensity}

The notion of 'entrepreneurial intensity' (Morris, Kuratko \& Covin 2010) was developed to evaluate the overall altitude of entrepreneurship amongst firms and individuals, and it captures the degree and frequency of entrepreneurship. It has been defined by Morris and Sexton (1996) as the amalgamation of the frequency of entrepreneurial activities and the degree of entrepreneurship, measured in terms of innovation, risk taking and proactivity. There are three dimensions of entrepreneurship in EI: innovativeness, risk taking and proactiveness (Covin \& Slevin 1989; Miles \& Arnold 1991). The innovativeness dimension entails the tactical pursuit of creative and novel solutions to problems and needs within a particular context (Prakash, Jain \& Chauhan 2015). The risktaking subconstruct entails the entrepreneur's readiness to commit a considerable amount of resources to the opportunities that arise although such opportunities have a 
reasonable chance of failure (Morris 2015). The risks taken by the entrepreneur are, however, calculated and manageable. The proactiveness dimension relates to the considerable determination, flexibility and capacity to look into the future (Prakash et al. 2015). Frequency in EI is understood as the number of entrepreneurial events that an entrepreneur undertakes. The term EI, therefore, refers to the variable nature of entrepreneurship within an individual. The EI notion is derived from the postulation that entrepreneurial conduct varies in its innovativeness, proactiveness and risk-taking characteristics (Prakash et al. 2015). Market irregularities provide the potential for entrepreneurs to create monetary returns by introducing new goods and services, markets, processes and raw materials previously unavailable (Kirzner 1979; Shane 2003). According to Shu et al. (2018), opportunity recognition is generally modeled as the outcome of a wide-ranging search that is targeted in a particular direction where an opportunity is to be discovered, and by occupying a central position, an entrepreneur is more likely to make sense of ambiguous situations and validate the information from different sources.

\section{Conceptual model and hypothesis development \\ Grounding theory}

This study's theoretical underpinnings draw inspiration from the SET, an influential theoretical paradigm that promotes the idea of two-sided relationships and reciprocal resources exchanging behaviours (Miles 2012). The SET has been understood as 'a general sociological theory concerned with understanding the exchange of resources between individuals and groups in an interaction situation' (Ap 1992:668). According to the SET, an entrepreneur's ability to establish high-quality business and social relationships are critical. It ensures that they benefit when the other party reciprocates the relationship by providing favours, helping the entrepreneur in market sensing and developing a cognitive structure for selecting and developing opportunities (Shu, Ren \& Zheng 2018). Within SET, parties are engaged in an exchange relationship because of the anticipated benefits expected where economic (product, service and knowledge) and social (friendship and reputation) resources are likely to be exchanged amongst different actors (Miles 2012).

\section{Conceptual model}

Based on the SET, this study suggests that social capabilities derived from business sociability, the entrepreneur's sociability, social presence and online social interactions will influence the firm's relationship quality whilst influencing EI. The underlying proposition is that to increase the entrepreneurs' EI, they must improve their social capabilities. The direct and indirect relationships between social capabilities and EI are represented in Figure 1.

There is proof in the existing literature that there is a relationship between social and psychological dimensions

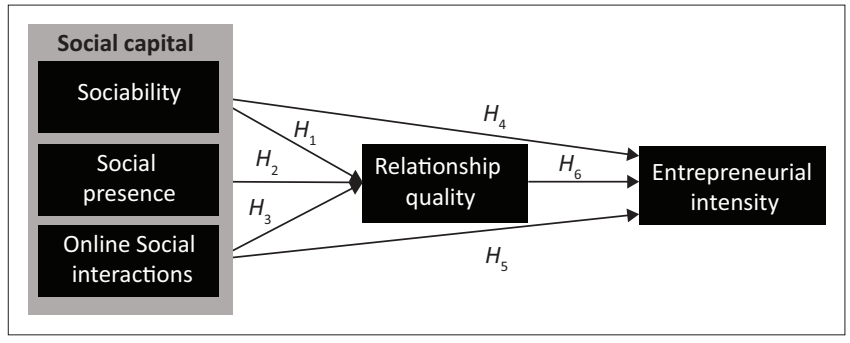

FIGURE 1: Conceptual model.

and organisational decision-support systems. These dimensions aid in the decision-making processes (Liberatore \& Quijano-Sanchez 2017; Quijano-Sanchez, Díaz-Agudo \& Recio-García 2014), hence the above pictorial representation.

\section{Hypothesis development}

The improvement in social capabilities achieved by the sustainable growth of interactions and relationship management is believed to enable the identification, organisation and resolution of socio-economic social challenges (Lee 2018). The recent development of smartphone technology has enabled instant interactions with friends and business partners, thereby potentially allowing improved benefits of social interactions (Dwyer, Kushlev \& Dunn, 2018). It has been empirically proven that social interactions and high-quality relationships are significant in many facets. O'Sullivan and Walker (2018) and Gonzalez et al. (2018) came to a similar conclusion that employment opportunities in developed economies are significantly found through informal contacts with colleagues, family or job service providers. Empirical research has proved that strong social relationships are valuable for individuals in providing social support (Zellweger et al. 2018) and comfort (Dunn 2018; Joly \& Connolly 2019), connections (Whelan, Hingston \& Thompson 2019), in supporting a positive mind-set and regularity in behaviour (Farrow \& Yuan 2011). In essence, the development network and social relationships are key factors influencing firms' and entrepreneurs' efficient performance (Prashantham et al. 2019; Smith, Smith \& Shaw 2017). Based on the arguments and empirical evidence, this study predicts that entrepreneurs who nurture their social capabilities are associated with high EI levels. Hence:

$H_{1} \quad$ There is a positive and significant relationship between sociability and relationship quality.

$H_{2}$ There is a positive and significant relationship between social presence and relationship quality.

$\mathrm{H}_{3} \quad$ There is a positive and significant relationship between online social interactions and relationship quality.

$H_{4} \quad$ There is a positive and significant relationship between sociability and EI.

$H_{5} \quad$ There is a positive and significant relationship between online social interactions and EI.

$H_{6} \quad$ There is a positive and significant relationship between relationship quality and EI. 


\section{Methodology Research approach and design}

This study on the relationship between social capabilities and EI adopted a positivistic paradigm and a quantitative approach. The positivist paradigm choice was influenced by the need to objectively and hence quantitatively analyse data to confirm the proposed relationships. According to Burns and Grove (1993), a quantitative approach is a formalised, objective process of describing and testing relationships amongst variables of interest. In terms of the research design, this study adopted a cross-sectional survey design to confirm the relationship's direction and magnitude without experimental manipulation.

\section{Development of measurement instrument}

Based on the conceptual model, a survey questionnaire was designed to measure the proposed constructs that contribute to EI. To ensure both validity and reliability of the measurement instrument, the items used to operationalise each construct were adapted from the previous literature. The questionnaire's measurement items were subjected to intensive review by three research experts to ensure reasonable consistencies, simplicity and contextual significance before distribution. Based on the reviewers' comments, the items were slightly modified. Furthermore, a pilot test was conducted involving 13 SMEs owners and managers, and also, based on their observations and suggestions, the items were modified accordingly. The questionnaire had four sections: the first section (Section A) looked at the respondent's biographic data, Section B solicited information on the Social Interaction construct and its three subconstructs, namely sociability, social presence and online social interaction. Sections C and D looked at relationship quality and EI, respectively. All construct items were assessed using a five-point Likert scale ranging from 1 (strongly disagree) to 5 (strongly agree).

\section{Sampling and data collection}

The population of interest in this study was SMEs, and to make the group manageable and feasible, the sampling frame was confined to those SMEs' owners and managers who are part of an online social group like WhatsApp or Facebook group. Theoretically, the population to be studied should comprise all SMEs in Zimbabwe but access to information, cost and time constraints, and privacy concerns make it difficult to include all SMEs. Therefore, a non-probabilistic sampling procedure (convenience sampling) was used to collect the data. An online questionnaire constructed using Google Docs was posted on Masvingo-centred Facebook and WhatsApp groups from 15 October 2018 to 19 December 2018. To eliminate repeated responses, responses with duplicate IP addresses were deleted, and this was done with the help of information systems experts and following the recommendations of Zhao et al. (2016). Of the 523 questionnaires retrieved in this web-based survey, 312 questionnaires were valid, giving an estimated response rate of $59.66 \%$. The demographic characteristics of the participants are presented in Table 1.
TABLE 1: Characteristics of the sample.

\begin{tabular}{lccccc}
\hline Characteristics & $\boldsymbol{n}$ & $\mathbf{\%}$ & $\boldsymbol{n}$ & $\mathbf{\%}$ \\
\hline Age in years & & & Level of education \\
Below 25 & 102 & 33 & High School/Technical College & 51 & 16 \\
$26-50$ & 125 & 40 & Undergraduate Degree & 232 & 74 \\
50 or older & 85 & 27 & Postgraduate Degree & 29 & 10 \\
Total & $\mathbf{3 1 2}$ & $\mathbf{1 0 0}$ & - & $\mathbf{3 1 2}$ & $\mathbf{1 0 0}$ \\
Annual turnover & & & Sector & & \\
\$0-\$2999 & 16 & 5 & Manufacturing & 72 & 23 \\
\$3000 to \$5999 & 97 & 31 & Retail & 188 & 60 \\
\$6000 to \$8999 & 109 & 35 & Tourism & 46 & 15 \\
\$9000 or more & 90 & 29 & Other & 6 & 2 \\
Total & $\mathbf{3 1 2}$ & $\mathbf{1 0 0}$ & - & $\mathbf{3 1 2}$ & $\mathbf{1 0 0}$ \\
\hline
\end{tabular}

The study results indicate that most of the respondents were aged between 26 and 50 years (40\%), followed by those below 25 with 33\%. The general thrust towards entrepreneurship in Zimbabwe could explain why there is a sizable number of entrepreneurs below 50. In addition, most of the respondents are fairly educated. Seventy per cent of the respondents have an undergraduate degree although a small number of them have moved on to acquire a postgraduate qualification $(10 \%)$. The businesses that these respondents represent have generally low levels of turnover. Most of the firms are below $\$ 9000$ in annual turnover, with only a small number (29\%) scoring above $\$ 9000$. This could be a result of the fact that SMEs are generally undercapitalised.

\section{Data analysis}

In this study, data analysis was conducted using the covariance based structural equation modelling technique (SEM). Structural equation modelling is a statistical and multivariate technique that uses pictorial representations to hypothesise complex relationships between independent constructs and the dependent variables. It allows the empirical assessment of hypothesis with or without latent variable structures, using statistical measures such as coefficient of determination $R^{2}$ (Mostafa \& Roorda 2019). This technique is growing in recognition, and several studies have adopted this technique across different disciplines demonstrate (Hair, Babin \& Krey 2017; Ringle, Sarstedt \& Straub 2012). The self-developed questionnaire was validated through confirmatory factor analysis (CFA), whilst the interrelationships amongst all variables were determined by using path analysis.

\section{Ethical considerations}

This article followed all ethical standards for a research without direct contact with human or animal subjects.

\section{Results}

\section{Confirmatory factor analysis}

A CFA was conducted using AMOS 25.0 to validate the measurement items for both reliability and validity. Reliability was examined using Cronbach's alpha $(\alpha)$, 
composite reliability (CR) and average variance extracted (AVE) for each construct. All constructs had Cronbach $\alpha$ values greater than 0.7 , which is regarded as the minimum value for confirming reliability in social studies (Taber 2018). The results presented in Table 2 indicate that Cronbach $\alpha$ ranged between 0.741 and 0.927 , indicating the acceptable reliability of constructs. A CFA was applied to assess the constructs' construct validity with AMOS 25.0. According to Campbell and Fiske (1959), there are two key construct validity dimensions: convergent and discriminant validity. In assessing convergent validity, three criteria recommended by Fornell and Larcker (1981) were applied, namely all factor loadings should exceed $0.7, \mathrm{CR}$ should exceed 0.7 and the AVE for each construct should exceed 0.5. All three conditions for convergent validity were met, as presented in Table 2 .

According to Gefen and Straub (2005:92), 'discriminant validity is shown when each measurement item correlates weakly with all other constructs except for the one to which it is theoretically associated'. Discriminant validity was assessed following the recommendations of Fornell

TABLE 2: Confirmatory factor analysis results.

\begin{tabular}{|c|c|c|c|c|}
\hline Constructs and Scale Items & $\begin{array}{l}\text { Standard } \\
\text { loading }\end{array}$ & CR & AVE & $\begin{array}{c}\text { Cronbach's } \\
\text { alpha }\end{array}$ \\
\hline Sociability & & 0.918 & 0.736 & 0.888 \\
\hline SOC1 & 0.879 & - & - & - \\
\hline SOC2 & 0.875 & - & - & - \\
\hline SOC3 & 0.799 & - & - & - \\
\hline SOC4 & 0.876 & - & - & - \\
\hline Social presence & & 0.876 & 0.639 & 0.749 \\
\hline SP1 & 0.789 & - & - & - \\
\hline SP2 & 0.875 & - & - & - \\
\hline SP3 & 0.714 & - & - & - \\
\hline SP4 & 0.811 & - & - & - \\
\hline Online social interactions & & 0.946 & 0.814 & 0.927 \\
\hline OSI1 & 0.897 & - & - & - \\
\hline OSI2 & 0.910 & - & - & - \\
\hline OSI3 & 0.879 & - & - & - \\
\hline OSI4 & 0.923 & - & - & - \\
\hline Relationship quality & & 0.832 & 0.557 & 0.897 \\
\hline RQ1 & 0.713 & - & - & - \\
\hline RQ2 & 0.698 & - & - & - \\
\hline RQ3 & 0.878 & - & - & - \\
\hline RQ4 & 0.678 & - & - & - \\
\hline Entrepreneurial intensity & & 0.821 & 0.535 & 0.741 \\
\hline El1 & 0.687 & - & - & - \\
\hline EI2 & 0.674 & - & - & - \\
\hline EI3 & 0.714 & - & - & - \\
\hline El4 & 0.840 & - & - & - \\
\hline
\end{tabular}

AVE, average variance extracted; $C R$, composite reliability.

TABLE 3: The correlation coefficient and average variance extracted.

\begin{tabular}{lcccccc}
\hline Variable & AVE & SOC & SP & OSI & RQ & EI \\
\hline Sociability (SOC) & 0.736 & $\mathbf{0 . 8 5 6}$ & - & - & - & - \\
Social Presence (SP) & 0.639 & 0.689 & $\mathbf{0 . 7 9 9}$ & - & - & - \\
Online Social Interaction (OSI) & 0.814 & 0.516 & 0.722 & $\mathbf{0 . 9 0 2}$ & - & - \\
Relationship Quality (RQ) & 0.557 & 0.636 & 0.719 & 0.691 & $\mathbf{0 . 7 6 0}$ & - \\
Entrepreneurial Intensity (EI) & 0.535 & 0.548 & 0.640 & 0.702 & 0.568 & $\mathbf{0 . 7 3 1}$ \\
\hline
\end{tabular}

Note: The bold figures represent the square root of average variance extracted (AVE) is shown on the matrix's diagonal; inter-construct correlations are shown off the diagonal. AVE, average variance extracted. and Larcker (1981). Remarkably, the Fornell-Larcker criterion is regarded as a benchmark approach in assessing discriminant validity in covariance-based SEM (Shah \& Goldstein 2006; Shook et al. 2004). In this study, as indicated in Table 3, the square root of the AVEs exceeded all other cross-correlations between the constructs in the model, indicating acceptable discriminant validity.

The goodness of fit indicates how well the model fits the data acceptably, and in this study, this was evaluated using the recommendations of $\mathrm{Hu}$ and Bentler (1999). The $\chi^{2} / \mathrm{df}$ was lower than 2 (1.951), whilst the root mean residual (RMR) and the root mean square error of approximation (RMSEA) were both below 0.08 (0.056 and 0.059 , respectively). Acceptable model fit is indicated by an RMSEA value of 0.06 or less (Hu \& Bentler 1999). The comparative fit index (CFI) for the model was 0.964 , and the acceptable model fit is indicated by a CFI value of 0.90 or greater ( $\mathrm{Hu} \&$ Bentler 1999). Overall the model fitted well with the data, allowing for path analysis and hypothesis testing.

\section{Structural model assessment and path analysis}

A structural model path analysis was conducted to evaluate the hypothesised relationships amongst the constructs of interest. In line with the criteria suggested by $\mathrm{Hu}$ and Bentler (1999), the findings suggest good model fit $\left(\chi^{2} / \mathrm{df}=1.950\right.$, $\mathrm{RMR}=0.072, \mathrm{RMSEA}=0.066, \mathrm{GFI}=0.925, \mathrm{AGFI}=0.889$, $\mathrm{NFI}=0.945, \mathrm{RFI}=0.936, \mathrm{IFI}=0.961, \mathrm{TLI}=0.955, \mathrm{CFI}=0.964$ ).

According to the results stated in Table 4, Sociability has a positive and significant relationship with relationship quality and so is social presence with relationship quality $(\beta=0.586$ and $\beta=0.624$ respectively) at $p<0.001$ level of significance. This implies that both $\mathrm{H} 1$ and $\mathrm{H} 2$ are fully supported. The other hypothesis $\mathrm{H} 3$ proposed is a positive and significant relationship between online social interactions and relationship quality. The results indicate that the $\beta$ coefficient for the path was $0.798, p<0.001$, which others support for H3. Sociability and online social interactions both had results supporting their respective hypotheses $(\beta=0.456, p>0.001$ and $\beta=0.542, p<0.001$ ), implying that both were found to be positively influencing EI and upholding $\mathrm{H} 4$ and $\mathrm{H} 5$. Like all the other hypotheses, H6 was supported at $\beta=0.340, p>0.001$, implying a positive and significant relationship between relationship quality and EI.

TABLE 4: Outcomes of path analysis and hypothesis tests.

\begin{tabular}{|c|c|c|c|c|}
\hline Hypothesis & Predicted Relationships & $\begin{array}{l}\text { Standard } \\
\text { Path } \\
\text { Loadings }\end{array}$ & $T$-value & $\begin{array}{l}\text { Hypothesis } \\
\text { Test } \\
\text { Outcome }\end{array}$ \\
\hline $\mathrm{H}_{1}$ & Sociability $\rightarrow$ Relationship Quality & 0.586 & 7.130 & Supported \\
\hline $\mathrm{H}_{2}$ & $\begin{array}{l}\text { Social Presence } \rightarrow \text { Relationship } \\
\text { Quality }\end{array}$ & 0.624 & 3.336 & Supported \\
\hline $\mathrm{H}_{3}$ & $\begin{array}{l}\text { Online Social Interactions } \rightarrow \\
\text { Relationship Quality }\end{array}$ & 0.798 & 10.559 & Supported \\
\hline $\mathrm{H}_{4}$ & $\begin{array}{l}\text { Sociability } \rightarrow \text { Entrepreneurial } \\
\text { Intensity }\end{array}$ & 0.456 & 2.774 & Supported \\
\hline $\mathrm{H}_{5}$ & $\begin{array}{l}\text { Online Social Interaction } \rightarrow \\
\text { Entrepreneurial Intensity }\end{array}$ & 0.542 & 4.569 & Supported \\
\hline $\mathrm{H}_{6}$ & $\begin{array}{l}\text { Relationship Quality } \rightarrow \\
\text { Entrepreneurial Intensity }\end{array}$ & 0.340 & 13.289 & Supported \\
\hline
\end{tabular}




\section{Discussion of the results}

Based on the SET and previous literature, the present research established and evaluated an integrated model on the influence of social capabilities, measured in terms of social interactions (sociability, social presence, online social interactions) and relational quality on EI. The results derived from SEM provide evidence that social capital and relational quality are empirically significant in enhancing EI. The social interaction dimensions affect relationship quality, positively influencing EI, measuring innovativeness, risk taking and proactiveness. These findings have several implications for SME owners and managers and entrepreneurs, who, in general, seek to understand how they might influence their EI. In addition to the above, it is evident from the results that whilst offline social capital, as previously theorised in the literature, continues to be significant, the results of this study suggest that the use of online platforms has also grown in significance to affect the benefits derived from relationships. These results are in line with $\mathrm{He}$ and $\mathrm{Li}$ (2020) and Hutchins et al. (2021) on the significance of online social interaction in the current social and business environment.

\section{Practical implications}

The findings from this study have practical implications for entrepreneurs. Firstly, whilst entrepreneurs may find significance in infrastructure and capital investment, it has emerged that it is equally important to invest in technology and mechanisms that allow for improved social interactions and relationship quality. It is broadly accepted that entrepreneurship is future oriented, and it 'works by making new connections' (Anderson, Drakopoulou Dodd \& Jack 2012:962) and because the future requires firms to be innovative, innovation demands that firms come up with a diverse system of network relationships (Partanen, Chetty \& Rajala 2014) that evolve around emergent and strategic interactions. Secondly, entrepreneurs and their senior management must support employees and technical staff initiatives to interact with stakeholders outside the confines of the workplace and official setups. This will improve the sociability and social presence, thereby promoting both relationship quality and EI. Policymakers seeking to enhance the growth in the number and quality of entrepreneurs can also use this study's results. It is also imperative that government and policymakers pay particular attention to enhancing access to information and communication technology (ICT) systems by SMEs. This could be achieved by reducing duties and levies on ICT gadgets imported for business purposes and subsidising broadband internet services providers' business packages. This will improve the accessibility of online services and social media and enhance social interactions and relationship quality.

Thirdly, by accepting the significance of social capital in enhancing the EI dimensions, entrepreneurs can enhance their access to critical resources that are necessary for growth and development. Sociability, offline and online interactions have proved viable alternatives for entrepreneurs seeking to increase their social capital. Kabonga, Zvokuomba and Nyagadza (2021) have noted the daunting challenge that entrepreneurs in Zimbabwe face in the resources necessary to ensure business growth. To assist in this process, these entrepreneurs need to be encouraged to create offline and online interaction platforms to help provide interconnections for sharing information and resources. Initiatives such as the Zimbabwe Informal Sector Association formed around 1996 in Harare (Mupedziswa \& Gumbo 2001) to coordinate the informal sector should be revived. These will enhance networking and coordination, thus building a culture that allows for entrepreneurs' social capital growth.

\section{Conclusion}

Despite the aforementioned research limitations, this study provides relatively strong evidence to support the notion that social capital and relationship quality predict EI. The findings suggest that to positively influence EI, entrepreneurs and SMEs should focus on social capabilities and relationship quality. Particularly, entrepreneurs should focus on online social interactions, which give the greatest direct and indirect effect on EI. Arguably, entrepreneurs who seek to improve on the frequency of entrepreneurial activities and the degree of entrepreneurship, measured in terms of innovation, risk taking and proactivity, should align themselves towards social capital and relationship quality. This study provides a valuable framework to understand how social connectedness and relationships can alter Zimbabwean entrepreneurs' circumstances to experience business growth and development.

\section{Limitations}

Despite the practical significance, these results are limited in several important ways. Firstly, although the cross-sectional data used during SEM in this study establishes a causal order regarding the relationship between social capital and EI, there was no robust control for all the potential confounding variables. Thus, there is a need for research that is more inclined towards the experimental design to reinforce this study's results. In a nutshell, although this study posits social capital and relationship quality as antecedents of EI, the causal relations linking these constructs need to be distinctly demonstrated by relevant research methodologies. Secondly, although the measurement instruments for all the constructs in this study were adopted from previously validated items and based on prior literature, this may not give adequate results because of failure to reflect the specific affordances, diversities and dynamism in the current business environment. Thirdly, this study focused on the city of Masvingo, which has a relatively small population compared to the whole Zimbabwean population. It is possible that different target groups could exhibit different patterns in relation to social capital, relationship quality and EI. Moreover, a nonprobability sampling technique was used in this study, limiting the generalisability of the results to the entire Zimbabwean population. In light of the above limitations, this study provides recommendations for further research. 


\section{Areas for future research}

By breaking the social capabilities construct into dimensions and subcontracts, this study provides a platform for future studies that employ techniques to determine the cause-effect relationships amongst constructs. Whilst the current research supports the significance of social capital in enhancing EI, entrepreneurs' initiative and commitment cannot be ignored as critical drivers of performance. For the benefit of entrepreneurship growth in Zimbabwe, future research can fuse these aspects in the model to explain the determinants of EI. Further research can also evaluate how cultures can influence the construction of social capital and relationship quality. Future research should consider extending the current study by examining the extent to which entrepreneurial orientation will mediate the relationship between social capital and EI using a geographically broader population. One of the limitations of the current study is that it was carried out in a single country context. As such, there is a need for cross-country research that will boost the theoretical model explaining the predictor and the outcome variables.

\section{Acknowledgements Competing interests}

The authors declare that they have no financial or personal relationships that may have inappropriately influenced them in writing this article.

\section{Authors' contributions}

W.M. and S.M. conceived of the presented idea. S.M. developed the theory and performed the computations. W.M. and D.P. verified the analytical methods. W.M. and D.P. did the final write up of the article. All authors discussed the results and contributed to the final manuscript.

\section{Funding information}

The authors received no financial support for the research, authorship and/or publication of this article.

\section{Data availability}

The data that support the findings of this study are available from the corresponding author, D.P., upon the reasonable request. The data are not publicly available because of restrictions, for example, their containing information that could compromise the privacy of research participants.

\section{Disclaimer}

The views expressed in the submitted article are his or her own and not an official position of the institution or funder.

\section{References}

Adusei, M., 2016, 'Does entrepreneurship promote economic growth in Africa?', African Development Review 28(2), 201-214. https://doi.org/10.1111/1467 8268.12190
Anderson, A.R., Drakopoulou Dodd, S. \& Jack, S.L., 2012, 'Entrepreneurship as connecting: Some implications for theorising and practice', Management Decision 50(5), 958-971. https://doi.org/10.1108/00251741211227708

Andriani, L. \& Christoforou, A., 2016, 'Social capital: A roadmap of theoretical and empirical contributions and limitations', Journal of Economic Issues 50(1), 4-22. https://doi.org/10.1080/00213624.2016.1147296

Ap, J., 1992, 'Residents' perceptions on tourism impacts', Annals of Tourism Research 19(4), 665-690. https://doi.org/10.1016/0160-7383(92)90060-3

Auzoult, L., Lheureux, F. \& Abdellaoui, S., 2016, 'Are entrepreneurial intentions selfregulated? self-consciousness, core self-evaluations and entrepreneurial intentions of higher education students', The Spanish Journal of Psychology 19, E38. https://doi.org/10.1017/sjp.2016.42

Bentler, P.M., 1999, 'Rites, wrongs, and gold in model testing', Structural Equation Modeling 7(1), 82-91.

Boada-Grau, J., Sánchez-García, J.C., Viardot, E., Boada-Cuerva, M. \& Vigil-Colet, A 2016, 'Adaptation of an entrepreneurial motivation scale into Spanish', anales de psicología 32(2), 571-577. https://doi.org/10.6018/analesps.32.2.217341

Borgonovi, F. \& Andrieu, E., 2020, 'Bowling together by bowling alone: Social capital and Covid-19', Social Science \& Medicine 265, 73-116.

Burns, N. \& Grove, S.K., 1993, The practice of nursing research: Conduct, critique and utilization, 2nd edn., W.B. Saunders, Philadelphia.

Burrus, D., 2010, 'Social networks in the workplace: the risk and opportunity of Business 2.0', Strategy \& Leadership 38(4) 50-53.

Campbell, D.T. \& Fiske, D.W., 1956, 'Convergent and discriminant validation by the multitrait-multimethod matrix', Psychological Bulletin 56(2), 81-105. https://doi. org/10.1037/h0046016

Cao, G., Duan, Y. \& Cadden, T., 2019, 'The link between information processing capability and competitive advantage mediated through decision-making capability and competitive advantage mediated through decision-making effectiveness', International Journal of Informa
https://doi.org/10.1016/j.ijinfomgt.2018.10.003

Carrillo Álvarez, E. \& Riera Romaní, J., 2017, 'Measuring social capital: Further insights', Gaceta sanitaria 31, 57-61. https://doi.org/10.1016/j.gaceta.2016.09.002

Choi, D. \& Kim, J., 2004, 'Why people continue to play online games: In search of critical design factors to increase customer loyalty to online contents', CyberPsychology \& behavior 7(1), 11-24.

Choi, Y.J. \& Luo, Y., 2015, '13-month-olds' understanding of social interactions', Psychological Science 26(3), 274-283.

Covin, J.G. \& Slevin, D.P., 1989, 'Strategic management of small firms in hostile and benign environments', Strategic Management Journal 10(1), 75-87.

Crawford, I. \& Harris, D., 2018, 'Social interactions and the influence of "extremists", Journal of Economic Behavior \& Organization 153, 238-266.

De Choudhury, M., Sundaram, H., John, A. \& Seligmann, D.D., 2010, 'Analyzing the dynamics of communication in online social networks', in Handbook of social network technologies and applications, pp. 59-94, Springer, Boston, MA.

Dimova, R. \& Pela, K., 2018, 'Entrepreneurship: Structural transformation, skills and constraints', Small Business Economics 51(1), 203-220. https://doi.org/10.1007/ s11187-017-9916-0

Dunn, K., 2018, 'Communicating corporate social responsibility in a social world: The effects of company-generated and user-generated social media content on CSR attributions and scepticism', Journal of Marketing Management 34(17-18), 15031529.

Dwyer, R.J., Kushlev, K. \& Dunn, E.W., 2018, 'Smartphone use undermines enjoyment of face-to-face social interactions', Journal of Experimental Social Psychology 78 233-239. https://doi.org/10.1016/j.jesp.2017.10.007

Dzisi, S., Odoom, F.D. \& Gligah, B., 2018, 'Entrepreneurship training and skills development in Africa: Evidence from Koforidua Technical University, Ghana' International Journal of Economics and Business Research 15(4), 509-523. https:// doi.org/10.1504/IJEBR.2018.092154

Eijdenberg, E.L., Thompson, N.A., Verduijn, K. \& Essers, C., 2018, 'Entrepreneurial activities in a developing country: An institutional theory perspective', International Journal of Entrepreneurial Behavior \& Research 25(3), 414-432. https://doi.org/10.1108/IJEBR-12-2016-0418

Farrow, H. \& Yuan, Y.C., 2011, 'Building stronger ties with alumni through Facebook to increase volunteerism and charitable giving', Journal of Computer-Mediated Communication 16(3), 445-464. https://doi.org/10.1111/j.1083-6101.2011.01550.x

Feeney, J. \& Fitzgerald, J., 2018, 'Attachment, conflict and relationship quality: Laboratory-based and clinical insights', Current Opinion in Psychology 25, 127131. https://doi.org/10.1016/j.copsyc.2018.04.002

Fischer, B.B., Queiroz, S. \& Vonortas, N.S., 2018, 'On the location of knowledgeintensive entrepreneurship in developing countries: Lessons from São Paulo, Brazil', Entrepreneurship \& Regional Development 30(5-6), 612-638. https://doi. org/10.1080/08985626.2018.1438523

Fornell, C. \& Larcker, D.F., 1981, 'Structural equation models with unobservable variables and measurement error: Algebra and statistics', Journal of Marketing Research 18(3), 382-388. https://doi.org/10.1177/002224378101800313

Gefen, D. \& Straub, D., 2005, 'A practical guide to factorial validity using PLS-Graph: Tutorial and annotated example', Communications of the Association for Information systems 16(1), 5. https://doi.org/10.17705/1CAIS.01605

Gonzalez, J.A., Ragins, B.R., Ehrhardt, K. \& Singh, R., 2018, 'Friends and family: The role of relationships in community and workplace attachment', Journal of Business and Psychology 33(1), 89-104. https://doi.org/10.1007/s10869-016-9476-3

Grabher, G. \& Ibert, O., 2014, 'Distance as asset? Knowledge collaboration in hybrid virtual communities', Journal of Economic Geography 14(1), 97-123. 
Hair, Jr., J.F., Babin, B.J. \& Krey, N., 2017, 'Covariance-based structural equation modeling in the Journal of Advertising: Review and recommendations', Journal of Advertising 46(1), 163-177. https://doi.org/10.1080/00913367.2017.1281777

Hamlin, J.K., Wynn, K., Bloom, P. \& Mahajan, N., 2011, 'How infants and toddlers react to antisocial others', Proceedings of the National Academy of Sciences 108(50), 19931-19936.

He, J. \& Li, Q., 2020, 'Can online social interaction improve the digital finance participation of rural households?', China Agricultural Economic Review 12(2) 295-313. https://doi.org/10.1108/CAER-11-2019-0213

He, X., Hu, D., Swanson, S.R., Su, L. \& Chen, X., 2018, 'Destination perceptions, relationship quality, and tourist environmentally responsible behavior', Tourism Management Perspectives 28, 93-104.

Henriksson, A., 2019, 'Singles' activities: Sociability and the ambiguities of singledom' Families, Relationships and Societies 8(1), 37-52. https://doi.org/10.1332/20467 4317X15015138368221

Herrero, C.E., 2015,' The credibility of social media in journalism', Transinformação $27(2), 165-171$.

Hoffmann, H. \& Söllner, M., 2014, 'Incorporating behavioral trust theory into system development for ubiquitous applications', Personal and Ubiquitous Computing 18(1), 117-128. https://doi.org/10.1007/s00779-012-0631-1

Hu, L.T. \& Bentler, P.M., 1999, 'Cutoff criteria for fit indexes in covariance structure analysis: Conventional criteria versus new alternatives', Structural Equation Modeling: A Multidisciplinary Journal 6(1), 1-55.

Huntley, J.K., 2006, 'Conceptualization and measurement of relationship quality: Linking relationship quality to actual sales and recommendation intention' Industrial Marketing Management 35(6), 703-714.

Huo, B., Tian, M., Tian, Y. \& Zhang, Q., 2019, 'The dilemma of inter-organizational relationships: Dependence, use of power and their impacts on opportunism', International Journal of Operations \& Production Management 39(1), 2-23. https://doi.org/10.1108/IJOPM-07-2017-0383

Hutchins, N., Allen, A., Curran, M. \& Kannis-Dymand, L., 2021, 'Social anxiety and online social interaction', Australian Psychologist 56(2), 142-153. https://doi.org/ 10.1080/00050067.2021.1890977

Huy, Q. \& Zott, C., 2019, 'Exploring the affective underpinnings of dynamic managerial capabilities: How managers' emotion regulation behaviors mobilize resources for capabilities: How managers' emotion regulation behaviors mobilize resources for
their firms', Strategic Management Journal 40(1), 28-54. https://doi.org/10.1002/ their firms

Hyun, S.S., 2010, 'Predictors of relationship quality and loyalty in the chain restaurant industry', Cornell Hospitality Quarterly 51(2), 251-267.

Japutra, A., Molinillo, S. \& Wang, S., 2018, 'Aesthetic or self-expressiveness? Linking brand logo benefits, brand stereotypes and relationship quality', Journal of Retailing and Consumer Services 44, 191-200.

Jelodar, M.B., Yiu, T.W. \& Wilkinson, S., 2016, 'A conceptualisation of relationship quality in construction procurement', International Journal of Project Management 34(6), 997-1011.

Jin, L., Chen, Y., Wang, T., Hui, P. \& Vasilakos, A.V., 2013, 'Understanding user behavior in online social networks: A survey', IEEE Communications Magazine 51(9), 144150

Joly, L.E. \& Connolly, J., 2019, 'It can be beautiful or destructive: Street-involved youth's perceptions of their romantic relationships and resilience', Journal of Adolescence 70, 43-52. https://doi.org/10.1016/j.adolescence.2018.11.006

Kabonga, I., Zvokuomba, K. \& Nyagadza, B., 2021, 'The challenges faced by young entrepreneurs in informal trading in Bindura, Zimbabwe', Journal of Asian and African Studies 56(8), 1-15. https://doi.org/10.1177/0021909621990850

Kamakula, M.K.R.R. \& Patro, C.S., 2019, 'Entrepreneurship as the vantage point', in D.B.A. Mehdi Khosrow-Pour (ed.), Advanced methodologies and technologies in digital marketing and entrepreneurship, pp. 445-456, IGI Global, Pennsylvania.

Khalis, A. \& Mikami, A.Y., 2018, 'Talking face-to-Facebook: Associations between online social interactions and offline relationships', Computers in Human Behavio 89, 88-97.

Kim, J., Song, H. \& Luo, W., 2016, 'Broadening the understanding of social presence: Implications and contributions to the mediated communication and online education', Computers in Human Behavior 65, 672-679. https://doi.org/10.1016/j. chb.2016.07.009

Kirzner, I.M., 1979, Perception, Opportunity and Profit, University of Chicago Press, Chicago.

Kreijns, K. \& Kirschner, P.A., 2002, 'Group awareness widgets for enhancing social interaction in computer-supported collaborative learning environments: Design
and implementation', in 32nd Annual Frontiers in Education, vol. 1, pp. T3E-T3E, and implementation', in

Kreijns, K., Kirschner, P.A., Jochems, W. \& Van Buuren, H., 2007, 'Measuring perceived sociability of computer-supported collaborative learning environments', Computers \& Education 49(2), 176-192. https://doi.org/10.1016/j.chb.2016.07.009

Lee, I., 2018, 'Social media analytics for enterprises: Typology, methods, and processes', Business Horizons 61(2), 199-210.

Liberatore, F. \& Quijano-Sanchez, L., 2017, 'What do we really need to compute the Tie Strength? An empirical study applied to Social Networks', Computer Communications 110, 59-74. https://doi.org/10.1016/j.comcom.2017.06.001

Liu, C.T., Guo, Y.M. \& Lee, C.H., 2011, 'The effects of relationship quality and switching barriers on customer loyalty', International Journal of Information Management 31(1), 71-79.

Lo, S.M., Zhang, S., Wang, Z. \& Zhao, X., 2018, 'The impact of relationship quality and supplier development on green supply chain integration: A mediation and moderation analysis', Journal of Cleaner Production 202, 524-535.
Lowenthal, P.R. \& Snelson, C., 2017, 'In search of a better understanding of social presence: An investigation into how researchers define social presence', Distance Education 38(2), 141-159. https://doi.org/10.1080/01587919.2017.1324727

Mazhambe, A., 2017, 'Assessment of the contribution of street vending to the Zimbabwe economy. A case of street vendors in Harare CBD', IOSR Journal of Business and Management (IOSR-JBM) 19(9), 91-100.

McLeod, L. \& MacDonell, S.G., 2011, 'Factors that affect software systems development project outcomes: A survey of research', ACM Computing Surveys (CSUR) 43(4), 24. https://doi.org/10.1145/1978802.1978803

Medina, L. \& Schneider, F., 2018, Shadow economies around the world: What did we learn over the last 20 years? IMF Working Paper No 18/17, International Monetary Fund, New York.

Miles, J.A., 2012, Management and organization theory: A Jossey-Bass reader, vol. 9 John Wiley \& Sons, Hoboken, NJ.

Miles, M.P. \& Arnold, D.R., 1991, 'The relationship between marketing orientation and entrepreneurial orientation', Entrepreneurship Theory and Practice 15(4), 49-66.

Mitchelmore, S. \& Rowley, J., 2013, 'Entrepreneurial competencies of women entrepreneurs pursuing business growth', Journal of Small Business and Enterprise Development 20(1), 125-142. https://doi.org/10.1108/14626001311298448

Morgan, R.M. \& Hunt, S.D., 1994, 'The commitment-trust theory of relationship marketing', Journal of Marketing 58(3), 20-38.

Moretta, T. \& Buodo, G., 2018, 'Modeling Problematic Facebook use: Highlighting the role of mood regulation and preference for online social interaction', Addictive Behaviors 87, 214-221. https://doi.org/10.1016/j.addbeh.2018.07.014

Morris, M.H., 2015, 'Dimensions of Perceived Risk in Organizational Buying Decisions', in Proceedings of the 1984 Academy of Marketing Science (AMS) Annual Conference, pp. 42-46, Springer, Cham.

Morris, M.H., Kuratko, D.F. \& Covin, J.G., 2010, Corporate entrepreneurship \& innovation. Cengage Learning, Cengage Learning EMEA, Hampshire.

Morris, M.H. \& Sexton, D.L., 1996, 'The concept of entrepreneurial intensity: Implications for company performance', Journal of Business Research 36(1), 5-13. https://doi.org/10.1016/0148-2963(95)00158-1

Mostafa, T.S. \& Roorda, M.J., 2019, 'A structural equation model of commercial vehicle ownership', in H. Briassoulis, D. Kavroudakis \& N. Soulakellis (eds.), The practice of spatial analysis, pp. 203-218, Springer, Cham.

Mueller, M.L., 2015, 'Hyper-transparency and social control: Social media as magnets for regulation', Telecommunications Policy 2015, 39(9), 804-810. https://doi. org/10.1016/j.telpol.2015.05.001

Mujeyi, K. \& Sadomba, W.Z., 2019, 'Unemployment and informal entrepreneurship in Zimbabwe: Implications for regional integration', in S.O. Oloruntoba \& M. Muchie (eds.), Innovation, regional integration, and development in Africa, pp. 251-266, Springer, Cham.

Mupedziswa, R. \& Gumbo, P., 2001, Women informal traders in Harare and the struggle for survival in an environment of economic reforms, Nordic Africa Institute, Uppsala.

Muzurura, J., 2019, 'Does corruption really affect the growth of entrepreneurship in Zimbabwe?', International Journal of Emerging Trends in Social Sciences 5(1) 33-46. https://doi.org/10.20448/2001.51.33.46

Napitupulu, D., Adiyarta, K., Syafrullah, M. \& Sutabri, T., 2018, 'Socio-technology analysis of SMEs readiness in quality management system implementation', in IOP Conference Series: Materials Science and Engineering, vol. 420(1), p. 012117, IOP Publishing, Bristol.

Niebel, T., 2018, 'ICT and economic growth - Comparing developing, emerging and developed countries', World Development 104, 197-211. https://doi.org/10.1016/ j.worlddev.2017.11.024

Nyoni, T. \& Bonga, W.G., 2018, 'What determines economic growth in Nigeria?', DRJ-Journal of Business and Management 1(1), 37-47.

O'Sullivan, S. \& Walker, C., 2018, 'From the interpersonal to the internet: Social service digitisation and the implications for vulnerable individuals and communities', Australian Journal of Political Science 53(4), 490-507. https://doi. org/10.1080/10361146.2018.1519064

Ojansivu, I. \& Alajoutsijärvi, K., 2015, 'Inside service-intensive projects: Analyzing inbuilt tensions', International Journal of Project Management 33(4), 901-916. https://doi.org/10.1016/j.ijproman.2014.11.001

Olavarría-Jaraba, A., Cambra-Fierro, J.J., Centeno, E. \& Vázquez-Carrasco, R., 2018, 'Relationship quality as an antecedent of customer relationship proneness: $A$ cross-cultural study between Spain and Mexico', Journal of Retailing and Consumer Services 42, 78-87. https://doi.org/10.1016/j.jretconser.2018. 01.011

Park, J. \& Lee, J., 2014, 'Knowledge sharing in information systems development projects: Explicating the role of dependence and trust', International Journal of Project Management 32(1), 153-165.

Partanen, J., Chetty, S.K. \& Rajala, A., 2014, 'Innovation types and network relationships', Entrepreneurship Theory and Practice 38(5), 1027-1055. https:// doi.org/10.1111/j.1540-6520.2011.00474.x

Prakash, D., Jain, S. \& Chauhan, K., 2015, 'Supportive government policies, locus of control and student's entrepreneurial intensity: A study of India', Journal of Global Entrepreneurship Research 5(1), 26. https://doi.org/10.1186/s40497Global Entrepr $0042-7$

Prashantham, S., Kumar, K., Bhagavatula, S. \& Sarasvathy, S.D., 2019, 'Effectuation, network-building and internationalisation speed', International Small Business Journal 37(1), 3-21. https://doi.org/10.1177/0266242618796145 
Quijano-Sanchez, L., Recio-Garcia, J.A., Diaz-Agudo, B. \& Jimenez-Diaz, G., 2013 'Social factors in group recommender systems', ACM Transactions on Intelligent Systems and Technology (TIST) 4(1), 8. https://doi.org/10.1145/2414425.2414433

Ringle, C.M., Sarstedt, M. \& Straub, D., 2012, 'A critical look at the use of PLS-SEM in MIS Quarterly', MIS Quarterly 36(1), iii-xiv. https://doi.org/10.2307/41410402

Scheepers, M.J., Hough, J. \& Bloom, J.Z., 2007, 'Entrepreneurial intensity: A comparative analysis of established companies in South Africa', South African Journal of Economic and Management Sciences 10(2), 238-255. https://doi. org/10.4102/sajems.v10i2.585

Shah, R. \& Goldstein, S.M., 2006, 'Use of structural equation modeling in operations management research: Looking back and forward', Journal of Operations Management 24(2), 148-169. https://doi.org/10.1016/j.jom.2005. 05.001

Shane, S.A., 2003, A General Theory of Entrepreneurship: The Individual-Opportunity Nexus, Edward Elgar Publishing, Cheltenham, United Kingdom

Shook, C.L., Ketchen, Jr., D.J., Hult, G.T.M. \& Kacmar, K.M., 2004, 'An assessment of the use of structural equation modeling in strategic management research', Strategic Management Journal 25(4), 397-404. https://doi.org/10.1002/smj.385

Short, J., Williams, E. \& Christie, B., 1976, The social psychology of telecommunications, Wiley, Toronto.

Siddiqui, S. \& Jan, S., 2017,' Strategic entrepreneurship amongst business women of Jammu \& Kashmir: Scale development and validation', Global Business Review 20 (2), 387-404.

Smith, C., Smith, J.B. \& Shaw, E., 2017, 'Embracing digital networks: Entrepreneurs' social capital online', Journal of Business Venturing 32(1), 18-34. https://doi. org/10.1016/j.jbusvent.2016.10.003

Stephens, H.M., Partridge, M.D. \& Faggian, A., 2013, 'Innovation, entrepreneurship and economic growth in lagging regions', Journal of Regional Science 53(5), 778-812. https://doi.org/10.1111/jors.12019

Su, L., Swanson, S.R. \& Chen, X., 2016, 'The effects of perceived service quality on repurchase intentions and subjective well-being of Chinese tourists: The mediating role of relationship quality', Tourism Management 52, 82-95.
Suseno, Y., 2018, 'Disruptive innovation and the creation of social capital in Indonesia's urban communities', Asia Pacific Business Review 24(2), 174-195. https://doi.org/ 10.1080/13602381.2018.1431251

Shu, R., Ren, S. \& Zheng, Y., 2018, 'Building networks into discovery: The link between entrepreneur network capability and entrepreneurial opportunity discovery', Journal of Business Research 85, 197-208.

Taber, K.S., 2018, 'The use of Cronbach's alpha when developing and reporting research instruments in science education', Research in Science Education 48(6), 1273-1296. https://doi.org/10.1007/s11165-016-9602-2

Tatone, D., Geraci, A. \& Csibra, G., 2015, 'Giving and taking: Representational building blocks of active resource-transfer events in human infants', Cognition 137, 47-62. https://doi.org/10.1016/j.cognition.2014.12.007

Walsh, G., Hassan, L.M., Shiu, E., Andrews, J.C. \& Hastings, G., 2010, 'Segmentation in social marketing: Insights from the European Union's multi-country, antismoking campaign', European Journal of Marketing 44(7/8), 1140-1164.

Wang, Y., 2016, 'Investigating dynamic capabilities of family businesses in China: A social capital perspective', Journal of Small Business and Enterprise Development 23(4), 1057-1080. https://doi.org/10.1108/JSBED-12-2015-0175

Whelan, J., Hingston, S.T. \& Thomson, M., 2019, 'Does growing up rich and insecure make objects seem more human? Childhood material and social environments interact to predict anthropomorphism', Personality and Individual Differences 137, 86-96. https://doi.org/10.1016/j.paid.2018.08.015

Zafar, A. \& Mustafa, S., 2017, 'SMEs and its role in economic and socio-economic development of Pakistan', International Journal of Academic Research in Accounting, Finance and Management Sciences 4(6), 1-16. https://doi.org/10.6007/IJARAFMS/ v7-i4/3484

Zellweger, T.M., Chrisman, J.J., Chua, J.H. \& Steier, L.P., 2018, 'Social structures, social relationships, and family firms', Entrepreneurship Theory and Practice 43(2), 207223. https://doi.org/10.1177/1042258718792290

Zhao, X., Xu, T., Liu, Q. \& Guo, H., 2016, 'Exploring the choice under conflict for social event participation', in International conference on database systems for advanced applications, pp. 396-411, Springer, Cham. 